\title{
Hemodynamic and thermoregulatory effects of xylazine-ketamine mixture persist even after the anesthetic stage in rats
}

\author{
[Efeitos hemodinâmicos e termorregulatórios da mistura cetamina-xilasina persistem \\ mesmo após o período anestésico em ratos] \\ C. Picollo ${ }^{1}$, A.J. Serra ${ }^{2}$, R.F. Levy ${ }^{1}$, E.L. Antonio ${ }^{1}$, L. dos Santos ${ }^{3}$, P.J.F. Tucci ${ }^{1 *}$ \\ ${ }^{1}$ Universidade Federal de São Paulo - São Paulo, SP \\ ${ }^{2}$ Universidade Nove de Julho - São Paulo, SP \\ ${ }^{3}$ Universidade Federal do Espírito Santo - Vitória, ES
}

\begin{abstract}
The xylazine-ketamine mixture $(\mathrm{KX})$ is an anesthetic approach commonly administered to assess cardiovascular function in rodents. This study aimed to examine if the cardiovascular and thermoregulatory effects of KX could persist after the anesthetic state ceased in rats. Male Wistar rats were anesthetized with K $(50 \mathrm{mg} / \mathrm{kg}) \mathrm{X}(10 \mathrm{mg} / \mathrm{kg})$ through the intra-peritoneal route. Hemodynamic and thermoregulatory repercussions were evaluated in animals in awake state, during an anesthetic depth and after complete recovery of anesthetized state. KX was efficient to significantly induce deep anesthesia in all rats after 10min. A complete recovery of anesthetized state was observed only after 210min. Compared with preanesthetic state and control animals that received no drug, KX induced a significant reduction of systolic and diastolic blood pressure at $10 \mathrm{~min}$. Hypotension was more prominent at $150 \mathrm{~min}$. The heart rate was also significantly reduced after $10 \mathrm{~min}$ of $\mathrm{KX}$ and the highest magnitude of bradycardia was observed at 30min. In addition, rectal temperature was markedly decreased at $30 \mathrm{~min}$ of $\mathrm{KX}$ and the higher reduction occurred at $150 \mathrm{~min}$. The hemodynamic and thermoregulatory effects of $\mathrm{KX}$ were maintained even after complete anesthetic recovery.
\end{abstract}

Keywords: anesthesia, hypotension, xylazine-ketamine, hemodynamics, thermoregulation

\section{RESUMO}

Objetivou-se com este estudo avaliar a persistência dos efeitos cardiovasculares e termorregulatórios da associação cetamina e xilasina $(C X)$ mesmo após o período anestésico em ratos. Ratos Wistar machos foram anestesiados com cetamina $50 \mathrm{mg} / \mathrm{kg}$ e xilasina $10 \mathrm{mg} / \mathrm{kg}$, por via intra-peritoneal. As repercussões hemodinâmica e termorregulatória foram avaliadas com os animais acordados, durante o período anestésico e após recuperação completa da anestesia. A CX foi eficiente em induzir significante regime anestésico em todos os ratos após 10min. A recuperação completa do estado de anestesia foi observada somente após $210 \mathrm{~min}$. Comparado com o estado pré-anestésico e com animais controles, que não receberam anestesia, a CX induziu significativa redução das pressões sistólica e diastólica aos 10min. A hipotensão foi mais evidente aos $150 \mathrm{~min}$ após $C X$. A frequência cardíaca também foi significativamente reduzida com 10min de CX e a bradicardia foi mais acentuada aos 30min. A temperatura retal foi reduzida aos 30min, sendo mais acentuada após 150 min de anestesia. Os efeitos hemodinâmicos e termorregulatórios da CX persistem mesmo após completa recuperação anestésica.

Palavras-chave: anestésico, cetamina-xilasina, hemodinâmica, termorregulação

\section{INTRODUCTION}

Although anesthesia is known to cause unfavorable effects on the cardiovascular function in small animals, various anesthetic schemes such as ketamine plus xylazine have been employed to induce sedation and immobility (Hart et al., 2001; Rodrigues et al., 2006).

Recebido em 16 de julho de 2011

Aceito em 15 de maio de 2012

*Autor para correspondência (corresponding author)

E-mail: pjtucci@ terra.com.br
Ketamine is a dissociative anesthetic from the cyclohexylamine family which promotes increases in heart rate and arterial pressure (Haskins et al., 1985). In an attempt to lessen these undesirable cardiovascular effects, ketamine has been used in mixture with an alpha-2 agonist of the nonopioid - xylazine family (Moens and Fargetton, 1990). Apparently, the ketamine (K) and xylazine (X) mixture indirectly affects circulatory 
hemodynamics, leading to hypotension and bradycardia in rodents (Kawara et al., 2005; Rodrigues et al., 2006). In this regard, studies that evaluated the hemodynamic repercussion of $\mathrm{KX}$ have focused only on pharmacologic effects during the anesthetic period (Rodrigues et al., 2006). Thus, there is no information of whether the hemodynamic changes induced by KX may persist after deep anesthesia. Therefore, the present study was carried out examine the effects of anesthetic conditions with $\mathrm{KX}$ on the cardiovascular hemodynamic of male Wistar rats, and special attention was given to evaluate if the effects of $\mathrm{KX}$ could persist after the anesthetic state ceases.

\section{MATERIALS AND METHODS}

Animals were cared for in compliance with the Principles of Laboratory Animal Care formulated by the National Institutes of Health (National Institutes of Health publication no. 96-23, revised, 1996) and "Princípios Éticos na Experimentação Animal do Colégio Brasileiro de Experimentação Animal". The protocol research was approved by the Ethics Research Committee at the Federal University of São Paulo, Brazil.

Fourteen male Wistar rats weighing 180 to $220 \mathrm{~g}$ were randomized in control group $(\mathrm{N}=7)$ or anesthetized group $(\mathrm{N}=7)$ with $\mathrm{K}(50 \mathrm{mg} / \mathrm{kg})$ plus $\mathrm{X}(10 \mathrm{mg} / \mathrm{kg})$ through intra-peritoneal (IP) route.

The right carotid artery of each rat was exposed and catheterized using polyethylene tubing filled with heparin (20units $/ \mathrm{mL}$ ). The free end of the catheter was brought subcutaneously to the back of the neck. Afterwards, two electrode leads were chronically implanted through a subcutaneous route to analyze through electrocardiograpy and were affixed to the nape of the neck. The control group animals underwent surgical procedures similar to the $\mathrm{KX}$ group.

Forty-eight hours after the surgical procedures the $\mathrm{HR}$, systolic (SBP) and diastolic (DBP) arterial blood pressures were recorded through the use of AcqKnowledge 3.5.7 software (Biopac Systems Inc.) in non-anesthetized awake conditions with free-moving (basal). Afterwards the animals were submitted to another KX. IP Dose,HR, SBP and DBP were analyzed at the following times: 10, 30, $60,90,150$ and $210 \mathrm{~min}$. Rectal body temperature was monitored at the time through hemodynamic parameters using a digital thermometer (Letica, Hb101/2; Spain). The control group was evaluated in the same way.
Reflex responses to stimuli touch on the tail, hind leg and eyelid, as well as body movement were considered to evaluate the anesthetic stage as previously described (Wixson et al., 1987a; Wixson et al., 1987b). Score 0 was considered as blunted response or movement while 3 was considered for awake status. The recovery anesthesia was defined as a total re-establishing of free body movements, as well as responses to stimuli.

Following experiments, the animals were killed in accordance with recommendations previously published (Close et al., 1996). For this, the animals were placed in a closed chamber for inhalation of an overdose of Halothane.

Data are presented as mean \pm SE. The Shapiro-Wilk specification test was used to verify approximately normal statistic distributions. Two-way ANOVA for repeated measures followed by Bonferroni poshoc were used to detect significant differences. The Kruskall-Waliss test was carried in non-parametric analysis to detect differences between groups. The Friedman test followed by Wilcoxon rank analysis was carried out to determine within-group differences. A $\quad \mathrm{P}<0.05$ value was considered significant.

\section{RESULTS}

The KX dose used was efficient to induce satisfactory anesthetic depth in all rats (Figure 1). The response to pinch stimuli on the tail, hind leg, eyelid and free body movements significantly disappeared $10 \mathrm{~min}$ after $\mathrm{KX}$ administration. The peak of anesthetic stage was reached after 30min. Figure 1 shows that a complete anesthetic recovery was noticed only after $210 \mathrm{~min}$.

Both SBP and DBP were significantly reduced at 10min after the KX injection (Figure 2). The hypotensitve peak was reached at $150 \mathrm{~min}$. The KX induced a pattern of prolonged hypotension, which did not return to basal levels until the end of the observation period, and even after complete anesthetic recovery. HR was found to be significantly reduced at $10 \mathrm{~min}$ after $\mathrm{KX}$ administration and the peak reduction was noticed at $30 \mathrm{~min}$. The Bradycardia was maintained until the end of the experimental time (Figure 2). The rectal body temperature was significantly decreased at $30 \mathrm{~min}$ and it was more accentuated after $150 \mathrm{~min}$ of anesthetic regime $\left(32.30 \pm 0.09^{\circ} \mathrm{C}\right)$. Similar to hemodynamic variables, the temperature reduction was maintained during the entire experimental period after the $\mathrm{KX}$ injection. 

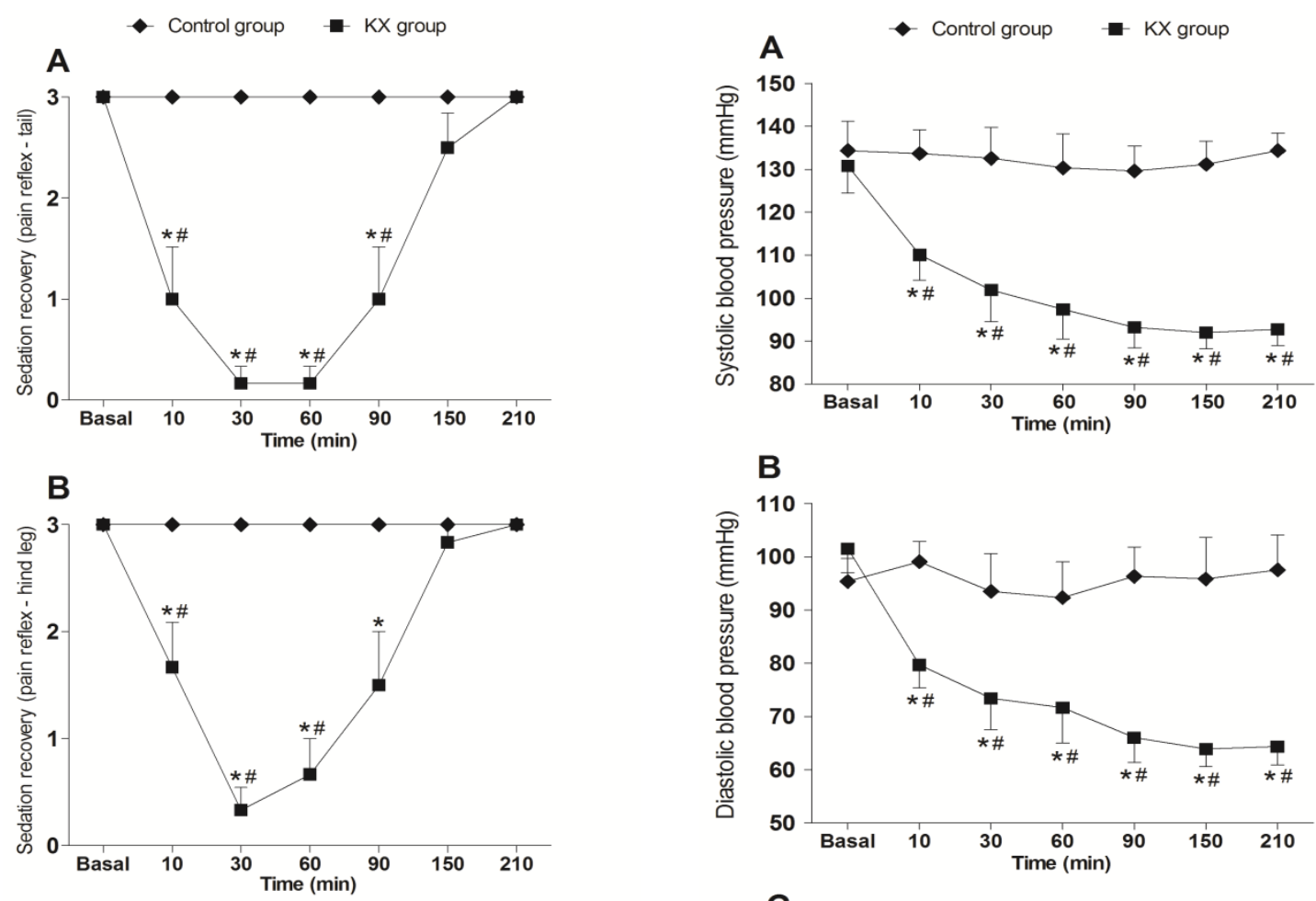

C
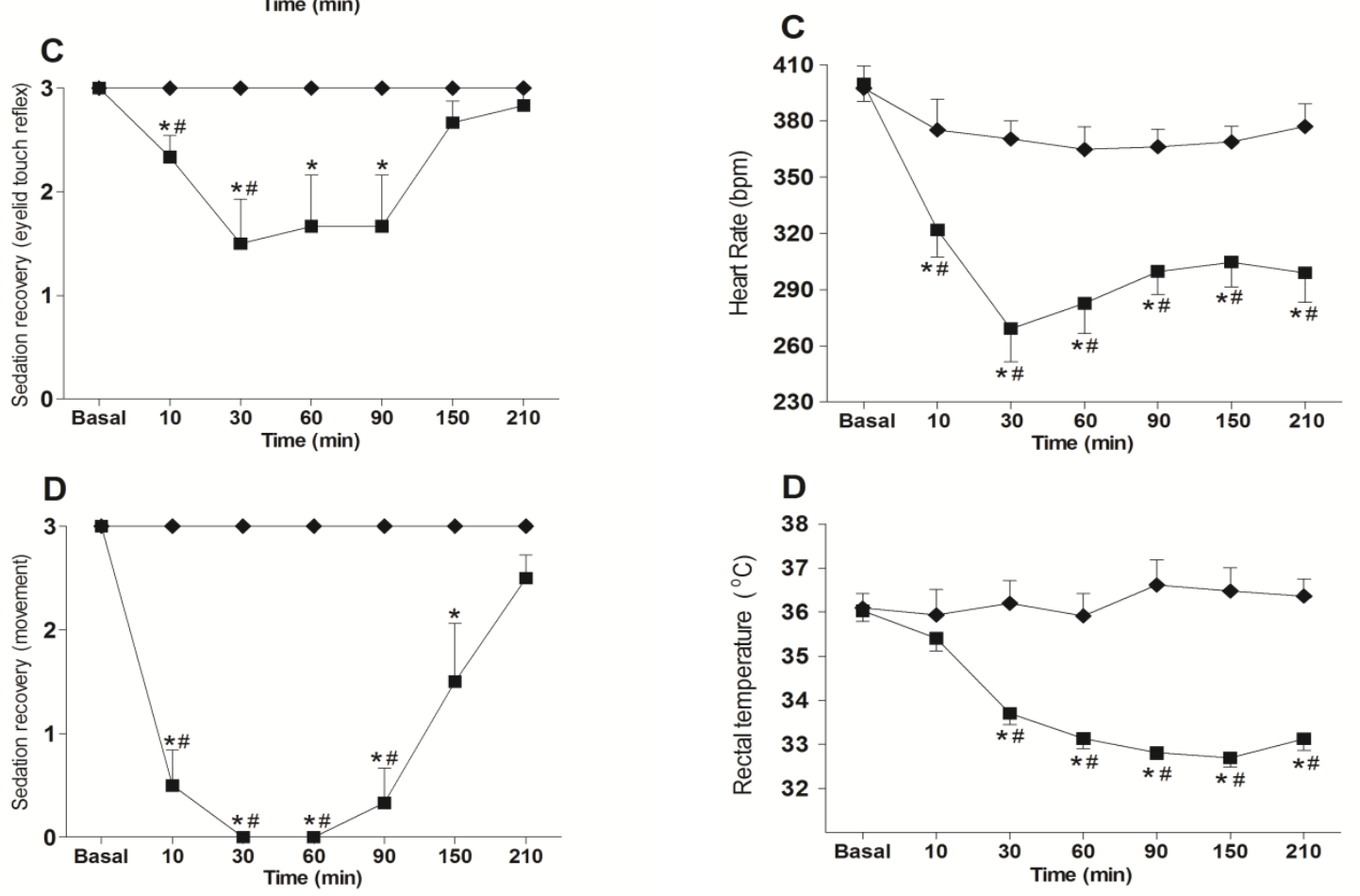

Figure 1. Behavioral responses to different stimuli on control and anesthetized groups in different time points. ${ }^{*} \mathrm{P}<0.05$ vs. control group in rats. ${ }^{\#} \mathrm{P}<0.05$ $v s$. conscious status.

Figure 2. Systolic (A) and diastolic (B) blood pressure, heart rate (C) and rectal body temperature (D) on control and anesthetized groups in different time points. $* \mathrm{P}<0.05$ vs. control group in rats. ${ }^{\#} \mathrm{P}<0.05$ vs. conscious status. 


\section{DISCUSSION}

This study was conducted to analyze the KX effects on hemodynamic and thermoregulatory parameters in rats. There was interest in evaluating whether the cardiovascular effects of KX could persist even after the complete recovery of consciousness state.

The KX mixture has proved to induce deep anesthesia and analgesia sufficient for surgical procedure. Many studies have demonstrated the efficacy of this anesthetic combination in rodents (Sumitra et al., 2004; Rodrigues et al., 2006). However, it is known that the anesthetics may promote significant hemodynamic changes, which can confuse cardiovascular analysis. Therefore, it was shown that $\mathrm{KX}$ promote sustained hypotension in rats, which is consistent with previous studies (Sumitra et al., 2004; Rodrigues et al., 2006), however, the point of interest that emerges from this study concerns the maintenance of hypotension even after anesthetic regimen. Interestingly, the hypotensive peak post-KX occurred at $210 \mathrm{~min}$, i.e. after anesthetic recovery. Moreover, we also demonstrated that the $\mathrm{KX}$ anesthesia reduced the $\mathrm{HR}$ in rats, which corroborates information from other researchers (Sumitra et al., 2004; Xu et al., 2007). As has been found for blood pressure, the bradycardia was maintained beyond the anesthetic period.

The mechanism by which the KX mixture induces hemodynamic changes is not clear. Several lines of evidence suggest that the xylazine action override, at least partially, the increased sympathetic action, the detrimental effect of baroreceptor feedback and the reduced vagal tone associated to ketamine (Haskins et al., 1985). It is plausible to accept that these mechanisms have been described as existing in the phase of deep anesthesia. Consequently, more studies are required to clarify the mechanisms responsible for maintaining reduced blood pressure and HR even after the anesthetic stage.

The results of the present study are consistent with previous findings, in which the KX mixture caused hypothermia in rats (Rodrigues et al., 2006). However, the description that the hypothermic state remains after the anesthetic stage is a novelty. This reduced temperature through KX anesthesia may be a consequence of a thermoregulatory depressant effect of ketamine (Chaves et al., 2001; Rodrigues et al., 2006). Although these effects can have negative consequences on animal experimentation, demanding higher postoperative care due to the intense hypotension and hypothermia, the reduced peripheral vascular resistance may exert a cardioprotective role after experimental procedures for cardiac damage, such as the induction of myocardial infarction.

\section{CONCLUSIONS}

The KX mixture changed the hemodynamic parameters and body temperature, and the hemodynamic changes through the use of $\mathrm{KX}$ anesthesia show results in potentially confounding variables for cardiovascular function. More importantly, these cardiovascular and thermoregulatory changes were maintained over time after cessation of anesthesia.

\section{ACKNOWLEDGEMENTS}

This study was partially funded by CAPES, $\mathrm{CNPq}$ and FAPESP.

\section{REFERENCES}

CHAVES, A.A.; WEINSTEIN, D.M.; BAUER, J.A. Non-invasive achocardiographic studies in mice influence of anesthetic regimen. Life Sci., v.69, p.213222, 2001.

CLOSE, B.; BANISTER, K.; BAUMANS, V. et al. Recommendations for euthanasia of experimental animals: Part 1. Lab. Anim., v.30, p.293-316, 1996.

HART, C.Y.; BURNETT Jr., J.C.; REDFIELD, M.M. Effects of avertin versus xylazine-ketamine anesthesia on cardiac function in normal mice. Am. J. Physiol. Heart Circ. Physiol., v.281, p.H1938-H1945, 2001.

HASKINS, SC.; FARVER, T.B.; PATZ, J.D. Ketamine in dogs. Am. J. Vet. Res., v.46, p.1855-1860, 1985.

KAWAHARA, Y.; TANONAKA, K.; DAICHO, T. et al. Preferable anesthetic conditions for echocardiographic determination of murine cardiac function. J. Pharmacol. Sci., v.99, p.95-104, 2005.

MOENS, Y.; FARGETTON, X. A comparative study of medetomidine/ketamine and xylazine/ketamine anesthesia in dogs. Vet. Rec., v.127, p.567-571, 1990. 
RODRIGUES, S.F.; OLIVEIRA, M.A.; MARTINS, J.O. et al. Differential effects of chloral hydrate- and ketamine/xylazine-induced anesthesia by the s.c. route. Life Sci., v.79, p.1630-1637, 2006.

SUMITRA, M.; MANIKANDAN, P.; RAO, K.V.K. et al. Cardiorespiratory effects of diazepam-ketamine, xylazine-ketamine and thiopentone anesthesia in male wistar rats-A comparative analysis. Life Sci., v.75, p.1887-1896, 2004.

XU, Q.; MING, Z.; DART, A.M. et al. Optimizing dosage of ketamine and xylazine in murine echocardiography. Clin. Exp. Pharmacol. Physiol., v.34, p.499-507, 2007.
WIXSON, S.K.; WHITE, W.J.; HUGHES Jr, H.C. et $a l$. The effects of pentobarbital, pentobartial, fentanyldroperidol, ketamine-xylazine and ketamine-diazepam on noxious stimulus perception in adult male rats. $L a b$. Anim. Sci., v.37, p.731-735, 1987a.

WIXSON, S.K.; WHITE, W.J.; HUGHES Jr, H.C. et al. A comparison of pentobarbital, fentanyl-droperidol, ketamine-xylazine and ketamine-diazepam anesthesia in adult male rats. Lab. Anim. Sci., v.37, p.726-730, $1987 b$. 